\title{
EFEKTIVITAS MENGUNYAH BUAH JAMBU AIR HIJAU CAMPLONG DAN BUAH JAMBU AIR KUSUMA MERAH TERHADAP PENURUNAN DEBRIS INDEKS
}

\author{
Ardi Tutur Pratama ${ }^{1}$, Silvia Prasetyowati ${ }^{2}$, Ida Chairanna Mahirawatie ${ }^{3}$ \\ ${ }^{123}$ Jurusan Keperawatan Gigi Politeknik Kesehatan Kementerian Kesehatan \\ Surabaya Email : ardipratama12@gmail.com
}

\begin{tabular}{|c|c|}
\hline & ABSTRAK \\
\hline \multirow[b]{2}{*}{$\begin{array}{l}\text { Kata Kunci : } \\
\text { Jambu Air Hijau; Jambu Air } \\
\text { Merah; Indek Debris. }\end{array}$} & Penelitian adalah kesehatan gigi dan mulut pada siswa kelas 4 SDN \\
\hline & $\begin{array}{l}\text { Batukerbuy IV Pamekasan yaitu tingginya angka debris indeks. } \\
\text { berdasarkan data pemeriksaan debris indeks yang dilakukan, } \\
\text { menunjukkan bahwa rata-rata debris indeks siswa sebesar } 2,01 \text { yang } \\
\text { termasuk dalam kategori buruk. Tujuan: untuk mengetahui } \\
\text { perbedaan efektivitas mengunyah buah jambu air hijau camplong } \\
\text { dan buah jambu air kusuma merah terhadap penurunan debris } \\
\text { indeks siswa-siswi kelas IV SDN Batukerbuy IV Pamekasan. } \\
\text { Metode: Jenis penelitian yang digunakan adalah penelitian } \\
\text { Eksperimen dengan rancangan pretest dan posttest desain. Subjek } \\
\text { penelitian terdiri dari } 40 \text { siswa, metode pengumpulan data dengan } \\
\text { cara observasi. teknik analisa data yang digunakan uji T tidak } \\
\text { berpasangan (independent sample T-test). Hasil: pada penelitian ini } \\
\text { diperoleh nilai Sig.(2-tailed) sebesar 0,035yang berarti nilai p } \\
\text { (signifikasi) lebih kecil dari nilai tingkat signifikan a }(0,05) \text {. Ada } \\
\text { perbedaan efektifitas mengunyah buah jambu air hijau camplong dan } \\
\text { buah jambu air kusuma merah terhadap penurunan debris indeks, } \\
\text { bahwa mengunyah buah jambu air hijau camplong lebih efektif } \\
\text { dibandingkan mengunyah buah jambu air kusuma merah }\end{array}$ \\
\hline & ABSTRCT \\
\hline $\begin{array}{l}\text { Key word: } \\
\text { Syzygium samarangense; } \\
\text { syzygium aqueum; Debris } \\
\text { Index }\end{array}$ & $\begin{array}{l}\text { In this study, the problem in the dental and oral health of } 4 \text { th-grade } \\
\text { students on Batukerbuy IV Elementary School Pamekasan is the } \\
\text { high number of index debris. Based on examination data, it shows } \\
\text { that the average student index debris of } 2.01 \text { is included in the bad } \\
\text { category.Objective: to find out the difference between the } \\
\text { effectiveness of chewing Syzygium samarangense and Syzygium } \\
\text { aqueum to reduce the debris index of students at Batukerbuy IV } \\
\text { Elementary School. Method: The type of research used was an } \\
\text { experimental study with a pretest and posttest design. The research } \\
\text { subjects consisted of } 40 \text { students, the method of data collection by } \\
\text { observation. The data analysis technique used is the independent } \\
\text { sample T-test. Results: In this study, the Sig (2- tailed) value of } 0.035 \\
\text { means that the p-value (significance) is smaller than the significance } \\
\text { level value of } \alpha \text { (0.05). There is a difference in the effectiveness that } \\
\text { chewing on the Syzygium samarangense is more effective than } \\
\text { chewing on Syzygium aqueum }\end{array}$ \\
\hline
\end{tabular}




\section{PENDAHULUAN}

Upaya pemeliharaan kebersihan dan pencegahan penyakit gigi dan mulut yaitu dengan cara menghindari atau sekurang kurangnya memperkecil terjadinya pembentukan debris, plak dan kalkulus. Makanan yang baik untuk pemeliharaan kebersihan gigi dan mulut adalah makanan yang mengandung serat dan air seperti buah-buahan dan sayuran, sedangkan makanan yang bisa mempengaruhi kebersihan gigi dan mulut adalah makanan yang manis dan lengket (Aljufri, Sriani 2018).

Makanan tersebut akan menempel pada permukaan gigi, apabila tidak dibersihkan nantinya akan membentuk deposit lunak yang mengandung berbagai macam mikrooganisme. Deposit lunak tersebut biasa disebut sebagai debris makanan. Debris berbeda dari plak karena kebanyakan debris akan liquifikasi oleh enzim bakteri dan bersih selama 5-30 menit, tetapi ada kemungkinan sebagian masih tertinggal pada permukaan gigi dan membran mukosa (Aljufri, Sriani 2018).

Plak yang melekat erat pada permukaan gigi dan gingival berpotensi cukup besar untuk menimbulkan penyakit pada jaringan keras gigi maupun jaringan pendukungnya. Keadaan ini di sebabkan karena plak mengandung berbagai macam jenis bakteri dengan berbagai macam hasil metabolismenya. Plak gigi tidak dapat dibersihkan hanya dengan cara kumur ataupun semprotan air. Plak hanya bisa dibersihkan secara sempurna dengan cara mekanis (Putri dkk, 2010). Apabila plak di biarkan lebih lama,maka akan terbentuk karang gigi atau kalkulus.

Kontrol plak dapat dilakukan seperti halnya kontrol debris yaitu dengan cara mekanis seperti menggosok gigi dan menggunakan benang gigi (flossing). Secara fisiologis Debris juga dapat dibersihkan dengan aliran saliva dan pergerakan otot-otot rongga mulut pada saat proses pengunyahan. Selain itu ada cara lain seperti berkumur, menghindari makanan yang mengandung sukrosa dan mengkonsumsi buah yang berserat dan berair (Purnomowati, Arianto 2016).

Penanaman gaya hidup sehat dengan memperhatikan pola makan berdasarkan jenis makanan yang baik untuk menjaga kebersihan gigi dan mulut sangat penting dalam meningkatkan status kebersihan gigidan mulut siswa. kebiasaan makan makanan yang berserat dan berair tidak bersifat merangsang pembentukan plak, melainkan berperan sebagai pengendali plak secara alamiah (self cleansing). Bahan makanan yang banyak mengandung serat dan air antara lain buah-buahan contohnya apel, jambu air, semangka, jambu biji, nanas dan sebagainya,serta sayur-sayuran dapat merangsang fungsi pengunyahan dan meningkatkan sekresi saliva. (Purnomowati, Arianto 2016)

Ada berbagai macam makanan berserat dan berair, yang dapat di peroleh di pasaran seperti buah - buahan yaitu jambu air (Eugenia Aquea) yang mempunyai kandungan gizi yang sangat kompleks guna upaya pemeliharaan kebersihan gigi dan mulut.

Presentasi penduduk yang mempunyai masalah kesehatan gigi dan mulut di Indonesia menurut Riskesdas tahun 2013 dan 2018 mengalami peningkatan dari 25,9\% menjadi sebesar $57,6 \%$ dan yang mendapatkan pelayanan dari tenaga medis gigi meningkat dari $8,1 \%$ menjadi $10,2 \%$.. Hal ini masih menjadi masalah,karena mengalami peningkatan yang sangat tinggi. (Infodatin 2019). 
Suatu keadaan yang menyatakan dimana seseorang mempunyai nilai OHIS (Oral Hygiene Index Simplified) yang tergolong dalam kategori baik, sedang dan buruk pada permukaan gigi seseorang maka menurut WHO standart OHIS di golongkan sebagai berikut:

Data yang telah di peroleh melalui pemeriksaan siswa-siswi kelas IV SDN Batukerbuy IV Pamekasan, di peroleh nilai debris indeks rata-rata 2.01 yang berada dalam kategori buruk. Bila dibandingkan dengan standart debris indeks, hasil survey yang telah di lakukan menunjukkan bahwa nilai debris indeks rata- rata siswa siswasiswi kelas 4 SDN Batukerbuy IV Pamekasan berada dalam kategori buruk yaitu diantara 1,9 - 3,0. Berdasarkan uraian data tersebut maka yang menjadi masalah disini adalah tingginya nilai debris indeks pada siswa-siswi kelas 4 SDN Batukerbuy IV Pamekasan.

\section{METODE}

Jenis penelitian yang digunakanm adalah Penelitian Quasi Eksperimen (Eksperimen semu) pre-test dan post-test. Untuk membandingkan efektivitas mengunyah buah jambu air hijau camplong dan buah jambu air kusuma merah pada siswa kelas 4 SDN Batukerbuy IV Pamekasan dengan siswa yang berjumlah 40. Metode pengumpulan data pada penelitian ini diperoleh dengan cara pemeriksaan langsung, dengan membagi dua kelompok yaitu kelompok mengunyah buah jambu air hijau camplong dan kelompok mengunyah buah jambu air kusuma merah. Dilakukan dengan mengukur kebersihan gigi dan mulut menggunakan metode Debris Indeks. Pemeriksaan dilakukan pada gigi indeks 16, 11, 26, 36, 31, 46 dengan skor indeks debris yaitu, 0-0.6 = kategori baik, 0.7-1.8 = kategori sedang, 1.9-3 = kategori buruk. Setelah data terkumpul maka dilakukan pengolahan data dan untuk membuktikan data tersebut normal atau tidak yaitu dengan menggunakan Kolmogorov-Smirnov. Kemudian hipotesis diuji dengan menggunakan T-test untuk membandingkan perbedaan antar 2 kelompok. Uji yang akan digunakan adalah uji paired sample T test untuk menghitung sebelum dan sesudah mengunyah buah, kemudian di uji menggunakan uji $\mathrm{T}$ tidak berpasangan (independent sample $T$ test) sehingga nantinya dapat diketahui apakah ada perbedaan antara mengunyah buah jambu air hijau camplong dan mengunyah buah jambu air kusuma merah terhadap penurunan debris indeks.

\section{HASIL DAN PEMBAHASAN}

Responden penelitian ini yaitu siswa kelas 4 SDN Batukerbuy IV Pamekasan dengan jumlah 40 siswa.

Tabel 1. Karateristik responden berdasarkan jenis kelamin

\begin{tabular}{ccc}
\hline Jenis kelamin & N & $\%$ \\
\hline Laki-laki & 25 & 62,5 \\
Perempuan & 15 & 37,5 \\
Total & 40 & 100 \\
\hline
\end{tabular}


Karateristik responden berdasarkan jenis kelamin dapat dilihat pada tabel 1 yang menunjukkan responden penelitian berjenis kelamin laki-laki sebanyak 25 siswa, dan berjenis kelamin perempuan sebanyak 15 siswa. Hasil penelitian pemeriksaan debris indeks dengan menggunakan cara perhitungan Green dan Vermilion. Pemeriksaan debris indeks dibagi menjadi empat yaitu pemeriksaan debris indeks sebelum mengunyah buah jambu air hijau camplong, kemudian pemeriksaan setelah mengunyah buah jambu air hijau camplong. Pemeriksaan sebelum mengunyah buah jambu air kusuma merah, dan pemeriksaan sesudah mengunyah buah jambu air kusuma merah.

Tabel 2. Hasil Pemeriksaan Debris Indeks sebelum mengunyah buah jambu air hijau camplong

\begin{tabular}{ccc}
\hline Kategori & N & \% \\
\hline Baik & 0 & 0 \\
Sedang & 7 & 35 \\
Buruk & 13 & 65 \\
Total & 20 & 100 \\
\hline
\end{tabular}

Data pada tabel 2 menunjukkan debris indeks sebelum mengunyah buah jambu air hijau camplong. Responden yang berada dalam kategori baik tidak ada $(0 \%)$, berada dalam kategori sedang 7 responden (35\%), dan yang berada dalam kategori buruk 13 responden $(65 \%)$.

Tabel 3. Hasil Pemeriksaan Debris Indeks setelah mengunyah buah jambu air hijau camplong

\begin{tabular}{ccc}
\hline Kategori & N & \% \\
\hline Baik & 4 & 20 \\
Sedang & 16 & 80 \\
Buruk & 0 & 0 \\
Total & 20 & 100 \\
\hline
\end{tabular}

Data pada tabel 3 menunjukkan debris indeks setelah mengunyah buah jambu air hijau camplong. Responden yang berada dalam kategori baik 4 responden (20\%), berada dalam kategori sedang 16 responden (80\%), dan yang berada dalam kategori buruk tidak ada (0\%).

Tabel 4. Hasil pemeriksaan debris indeks sebelum mengunyah buah jambu air kusuma merah

\begin{tabular}{ccc}
\hline Kategori & $\mathbf{N}$ & $\mathbf{\%}$ \\
\hline Baik & 0 & 0 \\
Sedang & 5 & 25 \\
Buruk & 15 & 75 \\
Total & 20 & 100 \\
\hline
\end{tabular}

Data pada tabel 4 menunjukkan debris indeks sebelum mengunyah buah jambu kusuma merah. Responden yang berada dalam kategori baik tidak ada (0\%), berada dalam kategori sedang 4 responden (25\%), dan berada dalam kategori buruk 12 responden $(75 \%)$. 
Home page: http://ejurnal.poltekkestasikmalaya.ac.id/index.php/jikg/index

Tabel 5. Hasil pemeriksaan debris indeks setelah mengunyah buah jambu air kusuma merah.

\begin{tabular}{ccc}
\hline Kategori & N & $\%$ \\
\hline Baik & 2 & 10 \\
Sedang & 18 & 90 \\
Buruk & 0 & 0 \\
Total & 20 & 100 \\
\hline
\end{tabular}

Data pada tabel 5 menunjukkan debris indeks setelah mengunyah buah jambu air kusuma merah. Responden yang berada dalam kategori baik 2 responden (10\%), berada dalam kategori sedang 18 responden (80\%), dan berada dalam kategori buruk tidak ada $(0 \%)$.

Tabel 6. Hasil analisis Debris indeks sebelum dan sesudah mengunyah buah jambu air hijau camplong dan buah jambu air kusuma merah.

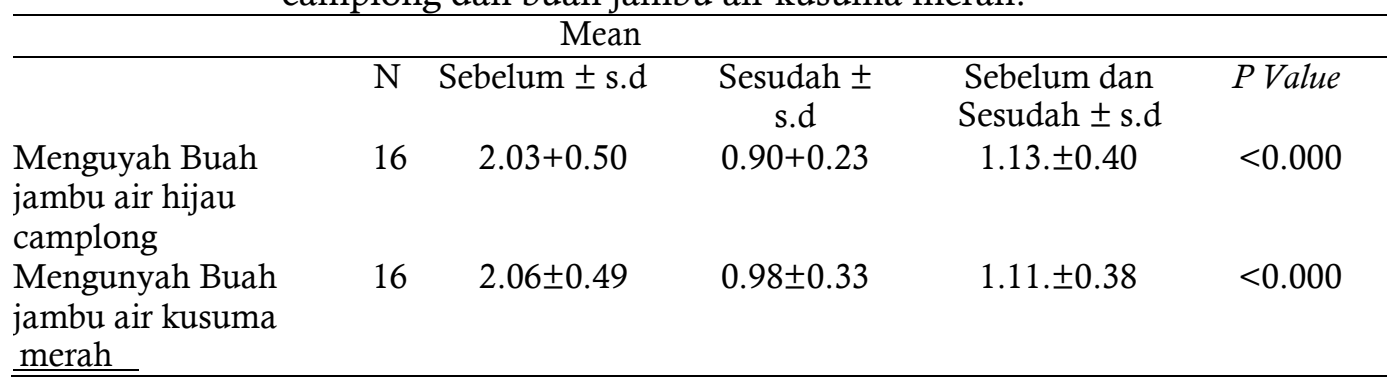

Data pada tabel 6 menunjukkan debris indeks setelah mengunyah buah jambu air hijau camplong dan buah jambu air kusuma merah. Dapat diketahui bahwa nilai mean sebelum mengunyah buah jambu air hijau camplong adalah 2.03 dengan standar deviasi 0.50 , nilai mean sesudah mengunyah buah jambu air hijau camplong adalah 0.90 , dengan standar deviasi 0.23 dan mean sebelum dan sesudah mengunyah buah jambu air hijau camplong 1.13 dengan standar deviasi 0.40 dan $P$ value $<0.000$ ( $P$ Value $<0.05)$ maka $\mathrm{H} 1$ diterima dan $\mathrm{H} 0$ ditolak artinya terdapat perbedaan debris indeks sebelum dan sesudah mengunyah buah jambu air hijau camplong. Sedangkan nilai mean sebelum mengunyah buah jambu air kusuma merah adalah 2.06 dengan standar deviasi 0.49 , nilai mean sesudah mengunyah buah jambu air kusuma merah adalah 0.98 dengan standart deviasi 0.33 , nilai mean sebelum dan sesudah mengunyah buah jambu air kusuma merah adalah 1.11 dengan standar deviasi 0.38 dan $P$ value 0.000 ( $p$ value $<0.05$ ), maka $\mathrm{H} 1$ diterima dan $\mathrm{H} 0$ ditolak yang artinya terdapat perbedaan debris indeks sebelum dan sesudah mengunyah buah jambu air kusuma merah.

Tabel 7. Hasil analisis perbedaan efektivitas mengunyah buah jambu air hijau camplong dan buah jambu air kusuma merah.

\begin{tabular}{lcc}
\hline & $\begin{array}{c}\text { Mean } \\
\text { Setelah } \pm \text { s. } \\
\mathrm{d}\end{array}$ & Sig.(2-tailed) \\
\hline $\begin{array}{l}\text { DI Setelah Mengunyah } \\
\text { Buah jambu air hijau camplong }\end{array}$ & $0.90 \pm 0.23$ & 0.035 \\
\hline $\begin{array}{l}\text { DI Setelah Mengunyah Buah } \\
\text { jambu air kusuma } \\
\text { merah }\end{array}$ & $0.98 \pm 0.33$ & \\
\hline
\end{tabular}


Data pada tabel 7 dapat diketahui bahwa nilai mean debris indeks sesudah mengunyah buah jambu air hijau camplong adalah 0.90 dengan standar deviasi 0.23 . Sedangkan nilai mean sesudah mengunyah buah jambu air kusuma merah adalah 0.98 dengan standar deviasi 0.33 dan nilai signifikasi atau sig. (2-tailed) = 0.035. oleh karena nilai sig.(2-tailed) < 0.050, maka hipotesis diterima. Dengan demikian dapat disimpulkan bahwa ada perbedaan efektivitas mengunyah buah jambu air hijau camplong dan buah jambu air kusuma merah terhadap debris indeks.

\section{PEMBAHASAN}

Berdasarkan analisis data menunjukkan bahwa ada perbedaan antara mengunyah buah jambu air hijau camplong dan buah jambu air kusuma merah terhadap penurunan nilai debris indeks pada siswa kelas 4 SDN Batukerbuy IV Pamekasan. Hasil tersebut menunjukkan bahwa kelompok mengunyah buah semangka lebih efektif dari pada mengunyah buah apel. Penelitian ini menunjukkan bahwa setelah mengunyah buah jambu air hijau camplong nilai debris indeks pada rongga mulut menjadi menurun, yang awalnya dengan katagori buruk menjadi sedang, tetapi buah jambu air kusuma merah juga mengalami penurunan yang lebih efektif dibandingkan dengan buah apel, yang awalnya dengan katagori buruk menjadi sedang, hanya saja yang membedakan antara dua perlakuan tersebut adalah jumlah angka penurunan debris indeks buah jambu air merupakan buah yang banyak serat dan air dan merupakan tanaman sumber vitamin, mineral, dan mengandung enzim. Dalam buah jambu air terdapat kadar air yang cukup tinggi yaitu sebesar 91,45g dan terdapat kadar serat sebesar 0,4g (Pujiastuti dkk (2015) Buah jambu air merupakan buah yang berserat dan berair, dan memiliki kandungan air cukup banyak maka secara langsung dapat menghambat pembentukan plak pada gigi. Kandungan air yang cukup banyak dalam semangka membuat buah ini bisa menjadi pembersih alami bagi gigi dan mulut, sehingga bisa mengurangi bau mulut. Adanya kandungan air yang banyak pada buah jambu air dapat menghilangkan plak yang sudah terbentuk.

\section{KESIMPULAN}

\section{SIMPULAN}

1. Rata-rata debris indeks siswa kelas IV SDN Batukerbuy IV Pamekasansebelum mengunyah buah jambu air hijau camplong dalam kategori buruk, sedangkan sesudah mengunyah jambu air hijau camplong termasuk dalam kategori sedang.

2. Rata-rata debris indeks debris indeks siswa kelas IV SDN Batukerbuy IV Pamekasan sebelum mengunyah buah jambu air kusuma merah dalam kategori buruk, sedangkan sesudah mengunyah buah jambu air kusuma merah termasuk dalam kategori sedang.

3. Terdapat perbedaan efektifitas mengunyah buah jambu air hijau camplong dan buah jambu air kusuma merahterhadap debris indeks pada Siswa Kelas IV SDN Batukerbuy IV Pamekasan Tahun 2020. 


\section{SARAN}

Berdasarkan hasil penelitian dan kesimpulan tersebut maka dapatdiberikan saran sebagai berikut :

\section{Bagi Guru SDN Batukerbuy IV Pamekasan}

Memotivasi siswa SDN Batukerbuy IV untuk mengkonsumsi makanan yang berserat dan berair seperti buah-buahaan seperti buah jambu air hijau camplong dan buah jambu air kusuma merah karena kedua buah tersebut bisa menjaga kebersihan gigi dan mulut terutama buah jambu air hijau camplong karena terbukti dapat menurunkan jumlah debris indeks serta menyampaikan kepada orangtua siswa ketika di adakan pertemuan wali murid untuk mengarahkan putra-putrinya mengkonsumsi makanan yang berserat dan berair.

2. Bagi Petugas Kesehatan

Menyarankan agar dalam menyampaikan materi pada saat memberikan penyuluhan terhadap anak sekolah isi dari pembahasan bisa berisi tentang manfaat dari mengkonsumsi buah berserat dan berair sebagai upaya mengurangi debris indeks yang dapat menjadi penyebab penyakit periodontal dan kerusakan gigi karena telah terbukti bahwa buah dapat menurunkan angka debris indeks karena mempunya sifat pembersihan secara alami (self cleansing).

\section{DAFTAR PUSTAKA}

Agrayni, Lysa, Yusliati, 2018. Efektifitas Rehabilitasi Pecandu Narkotika Serta Pengaruhnya Terhadap Tingkat Kejahatan Di Indonesia. Ponorogo: Uwais Inspirasi Indonesia. Hal.13.

Badan Penelitian dan Pengembangan Kesehatan, 2013. Riset Kesehatan Dasar (RISKESDAS) Laporan Nasional 2013. Hal.1. . 2018. Riset Kesehatan Dasar (RISKESDAS) Laporan Nasional 2018. Hal.1

Cahyati,Widya Hary, 2013. Konsumsi Pepaya (Carica Papaya) Dalam Menurunkan Debris Index. Jurnal Kesehatan Masyarakat Program Studi S3 Kedokteran dan Kesehatan Universitas Gadjah Mada Yogyakarta.

Haida, Cholil, Aspriyanto. 2014. Perbandingan Efektivitas Mengunyah Buah Pir dan Bengkuang terhadap Indeks Plak Siswa SDN Gambut 9 Kabupaten Banjar. Jurnal Kedokteran Gigi (Dentino) 2(1): 24-28

Hidayanti, Lina, Bachtiar 2013. Peran Buah dan Sayur dalam Menurunkan Keparahan Karies Gigi pada Anak. Jurnal Kesmas Unsoed.

Hidayat dan Tandiari, 2016. Kesehatan Gigi dan Mulut Apa yang Sebaiknya Anda Tahu.Yogyakarta: Andi. Hal.2-5, 24-35 
Hidayati, S. dan Suyatmi, D. (2016) "Pengaruh Mengunyah Buah Apel dan Buah Jambu Biji Merah Terhadap Debris Indeks," 03(2), hal. 42-46.

Listrianah (2017) "Hubungan Menyikat Gigi Dengan Pasta Gigi yang Mengandung Herbal Terhadap Penurunan Skor Debris Pada Pasien Klinik Gigi An-nisa Palembang," Jurusan Keperawatan Gigi Poltekkes Kemenkes Palembang, hal. 90.

Rifqi, Muhammad, (2017)." Pengaruh Konsumsi Buah Jambu Air (Syzygium Aqueum) Terhadap Indeks Plak Pada Siswa SMP Negeri 3 Dempet Demak" Fakultas Kedokteran Gigi, Universitas Muhammadiyah Semarang, hal 5-9

Pusat Bahasa Depdiknas,2002. Kamus Besar Bahasa Indonesia (Edisi Ketiga). Jakarta: Balai Pustaka.

Putri, A. Dhafin, 2017. Perbedaan Ph Saliva Dan Ph Plak Pada Penderita Diabetes Mellitus Tahap 2 Pada Pasien Ruma Sakit Umum Pusat Kariadi Semarang. Jurusan Sarjana Program Studi Pendidikan Dokter Fakultas Kedokteran Universitas Diponegoro. Hal. 40-44

Putri MH. Herijulianti E, Nurjannah N.Ilmu Pencegahan Penyakit Jaringan Keras dan Jaringan Pendukung Gigi. Jakarta: EGC Penerbit Buku Kedokteran. 2010. Hal.5560, 195-200.

Pujiastuti, Eny, 2015. Jambu Air Ekslusif. Jakarta: Trubus Swadaya. Hal.5-10. Pratiwi, Donna, 2009. Gigi Sehat dan Cantik Perawatan Praktis Sehari-Hari.Jakarta: Kompas. Hal.55-60.

Rahmawati, Y. Dhiah, 2011. Efektifitas Mengunyah Permen Karet Berxylitol Untuk Mengurangi Indeks Plak Gigi Siswa SDN Sekaran 1 Kabupaten Semarang. Jurnal Kedokteran (Dentino). Hal. 41-45

Sriyono, W. Niken, 2009. Pengantar Ilmu Kedokteran Gigi Pencegahan. Yogyakarta: Medika Fakultas Kedokteran Gigi UGM. Hal.22-24

Seajima dkk, 2015. Pengaruh Konsumsi Apel (Pyrus Malus) Terhadap Indeks Debris Pada Anak Usia 9 Tahun Di Sd Katolik St. Theresia Malalayang. Skripsi Program Studi Pendidikan Dokter Gigi Fakultas Kedokteran Program Studi Pendidikan Dokter Gigi Fakultas Kedokteran Universitas Sam Ratulangi Manado 